Scholedge International Journal of Business

Policy \& Governance

ISSN 2394-3351, Vol.05, Issue 05 (2018)

Pg 47-52.

DOI: 10.19085/journal.sijbpg050501
Published by: Scholedge Publishing

www.theSCHOLEDGE.org

Email: editorial@thescholedge.org

(C)Publisher

\title{
Trump, Xi and Game Theory
}

\author{
Prof Dr M S S El Namaki \\ Dean, Victoria University, School of Management, \\ Switzerland. Dean (Retired) Maastricht School of \\ Management, MSM, The Netherlands.
}

\begin{abstract}
Presidents Trump and Xi are approaching a game theory Nash construct. Both, predecessors included, have colluded into creating a race towards dominance of global trade, finance and technology. China by, primarily, enhancing the consumption share of US GDP and America by feeding Chinese insatiable hunger for technology. They created a dangerous measure of interdependence that translated into a mutually exclusive "win" situation. The game would have continued unchallenged was it not for President Trump's sudden realization that the probability of a win-win outcome is low. He then tampered with the underlying premises of the game and a new dynamic emerged. How will the game evolve? This will be the focus of the following article. The article applies an eclectic mix of conceptual frameworks including Game Theory, Nash equilibrium and Hofstede' culture consequences, among others, in order to formulate a likely scenario. It analytically places the two presidents within a Nash equilibrium prisoners' dilemma framework with each considering his strategic moves while eying shadow moves by the other.
\end{abstract}

\section{Game Theory and Nash Equilibrium.}

Game theory is "the study of mathematical models of conflict and cooperation between intelligent rational decision-makers" (Myerson B., 1991). Game theory examines the behavior of decision makers in situations of strategic interdependence. It provides a set of concepts for decision taking under conditions of competition and conflict. The founders, John Von Neumann and Oskar Morgenstern, laid down the conceptual foundation in their work "The Theory of Games and Economic Behavior" (1944). The strategic genre of the game theory works with players, player strategies and player outcome preferences. (Serdar Guner, Jun 21 2012).It operates with two rational strategy formulating players each with his own gain maximizing goals as well as his goal fulfilling strategies. Each is aware of the alternative courses of action open to the other and each aims at fulfilling his predetermined goals taking into consideration the probabilities of gain or loss inherent in the process. The outcomes and strategies are interdependent i.e. strategy to be adopted by one player will depend upon the strategy of the other. (Political ScienceNotes, 2017).

Nash equilibrium, a game theory derivative, assumes the existence of two (or more) players each with knowledge of the equilibrium strategies of the other andnone would gain from a unilateral change of his strategic course. Equilibrium connotes, here, a stable condition where forces cancel one another. The optimal outcome of the game is one where no player has an incentive to deviate from his chosen strategy after considering his opponent's choice. 


\section{Trump, Xi and Their Game}

Trump and Xi predicament is the outcome of both history and own ambitions. Both, predecessors included, have colluded into creating a race towards dominance of global trade, finance and technology. China by, primarily, enhancing the consumption share of US GDP and America by feeding Chinese insatiable hunger for technology. They, in this way, created a dangerous measure of interdependence that translated into a mutually exclusive "win" situation. The game would have continued unchallenged was it not for President Trump's sudden realization that the probability of a win-win outcome is low. He then tampered with the underlying premises of the game and a new dynamic emerged.

But how did they get into that position?

\section{How did PresidentTrump become a game player?}

Though recent events have much to do with the current Sino-American economic and political situation one has to go a long way to identify some of the forces that led to present day events. President's Trump's "prisoner" status is the result of following three dynamic force fields.

- Decade's long globalization drive. The strong Reagan initiated globalization drive that took place in the 80's deliveredintensive movement of capital and technology in both directions i.e. the USA and China. Reagan's doctrine", stimulated US FDI flow into China and a concurrent move by US MNC to establish a foothold in the country. And years later, a reverse FDI movement took place where Chinese capital went in search of M and A opportunities in the United States. Several strategic acquisitions were done by several Chinese MNCs includingHNL', Wanda. .and Alibaba.

- Established US global institutional commitments. US membership into WTO and China's admission to the organization in 2001 have created a global commitment for lower barriers to trade and a strict observance of a free flow of goods and services. A deviation would invite corrective action and, at times, sanctions. The mechanism that WTO had in place checked aberrations and worked as a barrier to rogue trade practices. President Trump's tariff and tariff barriers imposed on a wide collection of Chinese products signaled a departure from those collective rules of interaction. Threats of total withdrawal from an organization as the WTO separated President Trump from the international economic community and put him in a cell of his own.

- Personalitytraits. President Trump is not known for convention in either individual behavior or cross country formal decision making and communication. Penalizing tariff barriersimposed, hastily, on close allies under a national security pretext is not exactly in line with conventional cross country rules and traditions. Intensifying actual penalties and the promise of more constitutes a greater breach of decade long rules and norms. There are claims, by psychologyanalysts that President Trump has specific personality traits that are not exactly conducive to the international diplomacy convention. One of the most striking is the claim that he is "unusually self-confident, and "shows feelings of grandiosity and entitlement"(Sept 17, 2015 Psychology Today).

\section{And how did President Xi got entrapped?}

President's Xi difficult position is also the outcome of decades long economic and political developments as much as a vision of the China of tomorrow. A vision that sees China as a leader to a globalized world and a front runner in science and technology. This vision provided the inspiration and left clear prints on Chinese government programs and actions.

- The drive towards new globalization. President Xi made no secret of his drive to maintain the concepts of globalization as they have emerged in the eighties and to give those a new context and driving forces. BRI initiative demonstrated that. Trade, finance and enterprise were all included in a bold drive to create a new globalization marked by economic synergy, capital market dynamics, financial integration and last but not leased political empathy. This contrasted, heavily, with the isolationist noise coming from North American and revealed a chasm! 
- Strife for technological supremacy President Xi's assumption of a second term was followed by a number of bold steps aiming at the repositioning ofChina within the global technology arena. An ambitious plan was launched to dominate mobile technology, supercomputers, artificial intelligence and other cutting-edge industries andsubstantial resource were made accessible for that purpose. TheState Council also issueda document in July 2017 stating that china should assume the position of a global pre-eminent practitioner of artificial intelligence (AI) in both research and application within the next 12 years. "The situation is pressing. The challenges are pressing. The mission upon us is pressing," Xi said in Beijing at the opening of the joint annual conference of the Chinese Academy of Sciences and Chinese Academy of Engineering. "Selfdetermination and innovation is the unavoidable path ... to climb to the world's top as a leading player in technology," he said. (South China Morning Post, 28 May 2018).

- Falling in the US debt trap.Federal US debt has more than doubled since the 2008 financialcrisis. This was made manageable by a Federal Reserve emergency policy that envisaged an annual purchase of $\$ 500$ billion and a resort to foreign governments to cover the gap. China featured heavily in this scenario. The U.S. debt to China amounted to \$1.19 trillion in March 2018. That's 19 percent of the $\$ 6.29$ trillion in Treasury bills notes, and bonds held by foreign countries. This is a difficult position that does not lend itself to easy adjustment. A liquidation of these bond holdings, even partial, could cause major havoc in international market including an increasein costof US government borrowing as well as a serious undermining of equity markets.

\section{What is their common sin and where do they stand?}

The situation described above has led to structural flows that the two presidents, and their predecessors, directly and indirectlytriggered. China's exportdrive has, directly or indirectly, contributed to an imbalanced composition of US GDP and the emergence of consumption as the major driver (a near70\% over a number of years). US successive administrations have either encouraged or turned a blind eye to Chinese acquisition of Treasury Bills thus allowing for a measure of debt addiction and a stimulation of debt financed spending sprees. Successive US administrations have also encouraged US MNC investments in China and a corollary of US technology transfer to Chinese manufacturing entitiesthat undermined US competitiveness.

And a Nash equilibrium prisoners' dilemma junction emerged. Each of the two presidents formulated his own"remedial" strategy while keeping an eye on shadow moves by the other.Each playing within a functional force field built around situational economic and political currents and a cultural force field represented by an amalgam of respectivevalues, norms and traits. As forcefields overlap a number of scenarios emerge.

\section{Figure: Trump and $\mathrm{Xi}$ strategic alternatives.}

\section{(1) USA}

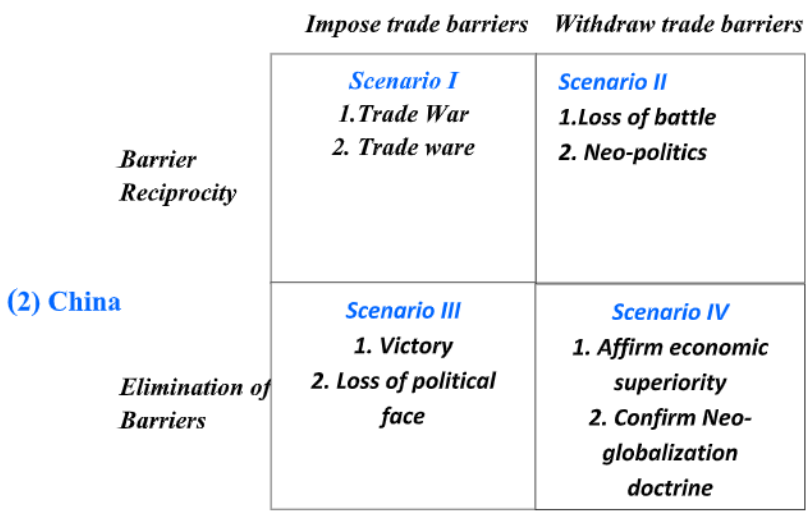

http://dx.doi.org/10.19085/journal.sijbpg050501 


\section{Scenario I: Trade war}

A short term solution to the problem seems unlikely. Neither side wants to be seen as weak. President Trump is chained to his election promises and President $\mathrm{Xi}$ is bound by the policy promise to make china a technology leader by 2025. And if Trump pushes for a radical change in China's underlying economic and political premises a war will it be. Long, intensive and ugly war.

\section{ScenarioII: US withdraw barriers while China persists.}

President Trump is under pressure to bring the China conflict to an end. Mid-term congressional elections, US industry and consumer voiced concerns, rural dismay at China's import trade restrictions are all triggers of unrest. China dismay at the very act may drag its feet in the face of a US government withdrawal.

\section{Scenario III. China withdraws barriers while the US persists.}

China's search for harmony may induce the government to offer a few concessions in anticipation of an American government favorable response. China would back down on technology issues and open its market to more American goods and services thismay not prove effective in the eyes of the United States.

\section{Scenario IV: Both would withdraw barriers and agree to an amicable reconciliation.}

This seems unlikely but possible. US demand for structural changes to the way China deals with technology development and acquisition and China has signaled a rejection of this stand. It sees that as a challenge to its Made-in-China 2025 blueprint. A change in the American political scene may result into a withdrawal of those constraining conditions and China may respond by a cosmetic move towards some technology policy liberalization.

\section{The most likely outcome.}

It is the authors' contention that culture will, very likely, play a major role in the search for a final outcome. Hofstede's concepts of culture and culture's consequences could help tracing a possible behavior of both players and an ultimate probable scenario. Hofstede attributes individual's decisions and behavior to five cultural traits that assume different attributes. There is individualism (vs. collectivism), uncertainty avoidance (vs.certainty_; high power distance (vs. low power distance), masculinity (vs. femininity)and long term orientation (vs. short term orientation). Analysis done by Hofstede and others reveals a marked difference between the US and the Chinese culture with regards to power distance, individualism, uncertainty avoidance and masculinity. (Hofstede, 2001)

\section{Figure}

US and China cultural traits according to Hofstede.

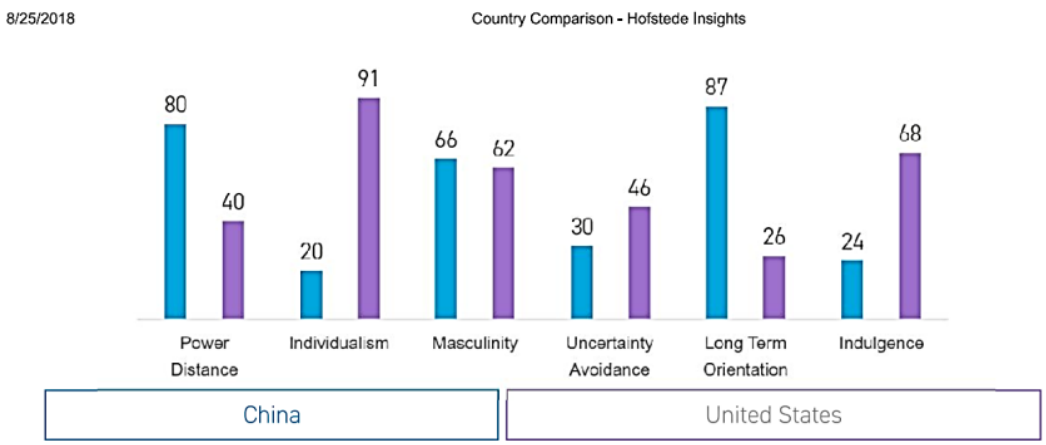

\section{Source : Hofstede Insights Culture Factor conference , 2018}

One can speculate a few possible implications of this disparity in cultural traits. One is the possible ability of President Xi to "sell" a concessionary conflict terms to his followers given the high power distance and the collectiveness of culture. Also the high propensity to avoid uncertainty. President Trump, on the other hand, will be under pressure to demonstrate his individuality and possibly, internal locus of control. He may also reflect a concern for issues as mid-term congressional elections rather than multi issue longer term relationship with China (or the EU for that matter). 
With those cultural traits in the background one can formulate a scenario where winning to Trump will be tantamount to prevailing in the battle of the tariffs. May be not that high, comprehensive, damaging or loud but a tariff it will;be .This would achieve several goals. Prime among them is fostering the image of ultimate resolution that Trump persistently advances. A secondary goal would be that of "teaching China a lesson" or penalizing China for abusing US trade and technology "innocence". And a third is shaking the foundations of what he terms "unfair" competitive environment of international trade or what we may term "slanted globalization". And another dimension of the winning will be a US economic counter offensive in the Asia Pacific region.This would, again, be part of the "lesson teaching" prong.

Winning to $\mathrm{Xi}$, if one is to use this unfitting term in this context, would constitute an appeal to the interest of the collective and a focus on the longer term. Put differently it will constitute a silent preservation of China's national vision and aspirations. This may entail a higher price for US technology input into the Chinese electronic and Artificial Intelligence-related industries as well as a measure of UScontrol over what happens to this technology. And a sign of consent to a review of WTO rules. An invisible element of this "win" would be the gradual depreciation of the RMB, a restriction of US MNC operations in China and a gradualincremental depletion of China's holdings of US Treasury bills. Measures will be spread over the medium term and avoid the appearance of revenge or bitter reaction.

How will those measures come to light will be subject to the environments of each head of nation? Culture will play a role here with high power distance and collectivism playing in the hands of President Xi while individualism and a short term orientation would taint PresidentTrump's ultimate decisions. PresidentXi's ultimate decisions would represent the sense of harmony and conciliatory spirit that China advocates. It will also stress the deep roots of multilateral trade and cooperative spirit of the Chinese leader. President Trump's ultimate scenario will reflect individual aura of victory and appeal to the conservative seminal believes of a segment of his population.Some of his personality traits as being highly mischievous, low on diligence and low on prudence could amplify this pattern. (Psychology Today, Sep 17, 2015)

All in all it seems as if the situation will become akin to a classic "Prisoners' Dilemma" where the players are likely to gravitate towards a bad "Nash" equilibrium, even when a good equilibrium is available through co-operative behavior. Both adopt protection. (FT)

\section{Summary and conclusions}

Presidents Trump and $\mathrm{Xi}$ are approaching a game theory Nash constructs. Both, predecessors included, have colluded into creating a race towards dominance of global trade, finance and technology. China by, primarily, enhancing the consumption share of US GDP and America by feeding Chinese insatiable hunger for technology. They created a dangerous measure of interdependence that translated into a mutually exclusive "win" situation. The game would have continued unchallenged was it not for President Trump's sudden realization that the probability of a win-win outcome is low. He then tampered with the underlying premises of the game and a new dynamic emerged.

How will the game go? And what could constitute conceptually defendable probable outcomes? This will be the focus of the following article.

One could analytically place the two presidents into a Nash equilibrium prisoners' dilemma framework with each considering his strategic moves while eying shadow moves by the other. It is the author's contention that culture will influence the negotiations and the possible outcomes. Hofstede's high power distance and collectivism parameters will play in the hands of President Xi while the other Hofstede's parameters; individualism and a short term orientation, will be shaping President Trump's ultimate options. President Xi's ultimate decisions will be, very likely, influenced by his own vision, aspirations and longer term goals as much as national sense of history and "justice". President Trump's ultimate scenario could reflect his individual aura of victory and appeal to the conservative seminal believes of a segment of his population. Some of his personality traits as being highly mischievous, low on diligence and low on prudence could amplify this pattern. (Psychology Today, Sep 17, 2015)

This should lead to a situation where both presidents adhere to their original strategies but formulate a conciliatory mantel.

http://dx.doi.org/10.19085/journal.sijbpg050501 
The article applies an eclectic mix of conceptual frameworks including Game Theory, Nash equilibrium and Hofstede' culture consequences among others.

\section{References}

[1]. Myerson, Roger B. (1991). Game Theory: Analysis of Conflict, Harvard University Press

[2]. World Trade Policy and the Game Theory - Overcoming the Prisoner's Dilemma?, GRIN Publishing ,Open Publishing GmbH, München, 2004.China is winning the global tech race, FT, June 17, 2016

[3]. https://journal-neo.org/2018/06/01/usa-in-a-debt-trap-death-spiral

[4]. Osborne, Martin J.; Rubinstein, Ariel (1994). A Course in Game Theory. Cambridge, MA.

[5]. World Trade Policy and the Game Theory - Overcoming the Prisoner's Dilemma?, Diploma Thesis, 2004, International Journal of Business, Humanities and Technology, Vol. 3 No. 2; February 2013

[6]. Khairullah D, Cultural Values and Decision-Making in China, International Journal of Business, Humanities and Technology, Vol. 3 No. 2; February 2013

[7]. Williams G, "Why China will win the global race for complete AI dominance", Wired, 16 April, 2018.

[8]. Leonard J, Mayeda A and Pickert Rm "Here is how a trade war between the US and China could play out", Bloomberg, June 15, 2018.

[9]. Sherman R, "The personality of Donald Trump, What the science of personality can tell us about the Republican front runner", Psychology Today, Sept $17 \mathrm{~m} 2015$.

[10]. Trade wars and the prisoners' dilemma, FT, March 25, 2018

[11]. A Short Note on the Use of Game Theory in Analyses of International Relations, Serdar Guner, Jun 212012

[12]. Iñaki Aguirre , Notes on Non-Cooperative Game Theory Microeconomic Theory IV 3º - LE-: 2008-2009

[13]. (https://www.ft.com/content/d288a98e-2e90-11e8-9b4b-bc4b9f08f381)

[14]. South China Morning Post, 28 May 2018

[15]. Hofstede, Geert (2001). Culture's Consequences: comparing values, behaviors, institutions, and organizations across nations (2nd Ed.). Thousand Oaks, CA: SAGE Publications. ISBN 978-0-8039-7323-7. OCLC 45093960.

[16]. Hofstede Insights Culture Factor conference, 2018.

Disclaimer: The content of the article is the analysis and opinion of the authorship. 